\title{
QUALITY ASSESSING OF COMMERCIAL ROE PRODUCTS FROM ALASKA POLLOCK ROE
}

\section{Chaoping CHEN, Bai LU, Emiko OKAZAKI and Kazufumi OSAKO*}

Department of Food Science and Technology, Tokyo University of Marine Science and Technology. Minato - ku, Tokyo 108-8477, Japan.

*e-mail: osako@kaiyodai.ac.jp

\begin{abstract}
Objective evaluation of commercial spicy pollock roes was conducted. Ovary weight, ovary length, ovary membrane thickness, egg diameter, $\mathrm{pH}$, color parameters, chemical composition, mechanical properties and protein composition were included in the evaluation items. The measurements of size, $\mathrm{pH}$, color parameters, chemical composition and free amino acid may be not suitable for assessing the quality of commercial spicy pollock roe in the current industry, as they do not differ much between high-priced and low-priced products. However, we found that most of products showed significant differences in ovary hardness between them. Therefore, we propose the measurements of mechanical properties such as ovary hardness as objective quality assessing methods.
\end{abstract}

Keywords: Alaska pollock roe ,Chemical composition, Ovary hardness

\section{INTRODUCTION}

Alaska pollock or walleye pollock (Theragra chalcogramma), a number of the cod family, which support one of the largest single-species fisheries in the world, is a semipelagic schooling fish widely distributed in north temperate and arctic waters of the North Pacific Ocean and is exploited by a variety of countries, including Japan, Canada, Korea, Russia and the United States of America (Responsible Sourcing Guide: Alaska pollock roe 2011 ). As availability of wild stocks decreases according to study of Broadus (1994), a better utilization is necessary.

The roe from pollock is commercially important, occupy $5 \%$ of the weight of the fish, and contribute about $31 \%$ of the value from pollock products (Balaban and Cirban 2012).

Alaska pollock roe has been used as food material for a long history. The roe from prespawning pollock usually processed to the spicy salted Alaska pollock roe products (usually abbreviated as spicy pollock roe), a kind of popular seafood sold at high prices in Japan and Korea (so called mentaiko in Japanese and myungran jeot in Korean). In recent years, the market size of spicy pollock roe has been decreasing in Japan, which is due to the decreasing of production volume and is mainly due to the decreasing of average price.

In Japan, commercial roe products are classified into two grades: high-priced products (about 1000 yen/100g) and low-priced products (about 400yen/100g). However, little research about the objective differences between high-priced and low-priced roe products was reported. Therefore, we aim at clarifying the differences between high-priced and lowpriced products. 


\section{MATERIAL AND METHODS}

High-priced spicy pollock roe products (about $1000 \mathrm{en} / 100 \mathrm{~g}$ ) and low-priced (about $400 \mathrm{en} / 100 \mathrm{~g}$ ) from five companies in Japan were sampled.

Ovary membrane thickness and egg diameter were measured by a RHEONER II creep meter (RE2-33005B, YAMADEN co., Itd., Tokyo, Japan) equipped with a cylindrical plunger (diameter, $8 \mathrm{~mm}$ ) with a raising rate of the sample table at $1 \mathrm{~mm} / \mathrm{s}$. During the measurement of ovary membrane, the touch between the cylindrical plunger and big blood vessels appeared in the ovary membrane was avoided.

For measuring $\mathrm{pH}, 10 \mathrm{~g}$ egg was sampled in beaker, $90 \mathrm{~g} \mathrm{IEW}$ (ion exchanged water) was added into the beaker, and was homogenized using a homogenizer (DIAX600, Nikko Hansen \& Co., Ltd. Japan), and then the $\mathrm{pH}$ of suspension was measured by using a $\mathrm{pH}$ meter (pH2 11 , Hanna Instruments Co., Ltd., Japan).

The color of a specimen was measured for its $L^{*}, a^{*}$ and $b^{*}$ values (CIE Laboratory system) by using a color reader (CR-13, Konica Minolta Sensing Inc., Tokyo, Japan).

The same commercial products were subjected to chemical composition analysis including moisture, ash, and crude protein according to the method of AOAC (1999). Protein content was determined by the Kieldahl method (AOAC, 1999) and a nitrogen conversion factor of 5.4 was used for calculation of protein content (Eastoe \& Eastoe, 1952). Crude lipid was extracted according to the Folch et al. procedure (1957).

The ovary hardness was assessed by measuring the strength when the strain was $50 \%$ on a RHEONER II creep meter (RE2-33005B, YAMADEN co., Itd., Tokyo, Japan) equipped with a cylindrical plunger (diameter, $16 \mathrm{~mm}$ ) with a raising rate of the sample table at $1 \mathrm{~mm} / \mathrm{s}$.

\section{RESULTS AND DISCUSSION}

Ovary weight values of high-priced products from some of the companies (especially $C$ company) were higher than those of low-priced products from the same companies. The ovary length of high-priced spicy pollock roe products and those of low-priced spicy pollock roe products also did not show obvious differnces. The values of ovary membrane thickness of all the products were similar. The egg diameter of high-priced products showed narrow range compared to that of low-priced products. The $\mathrm{pH}$ evaluation showed that all the products were acidulous and did not change much.

The color tone test showed that only products from A and C company showed obvious different $L^{*}$ values between high and low-priced products. Only the differences of $a^{*}$ value between high and low-priced products from $A$ and $D$ company were obvious. Among the five companies, the differences of $b^{*}$ value between high-priced and low-priced products from $C$ and $\mathrm{E}$ company were obvious. Based on communications with producers of spicy pollock roe, we realized that, sometimes, nitrite and colorings were added to make the appearance of their products look like fresher. 
Most of the differences in chemical compositions between high-priced products and lowproducts were not significant. Only the differences in moisture and ash content between highpriced products and low-priced products from A company were significant.

Therefore, measurements of, sizes, $\mathrm{pH}$ color tone and chemical compositions may not be suitable as a quality assessing method.

Except for those of products from B company, the ovary hardness values of high-priced products were higher than those of low-priced products significantly. It suggested that mechanical assessing is effective for quality assessing of commercial roe products from Alaska pollock.

\section{REFERENCE}

AOAC. (1999). Official methods of analysis (14th ed.). Washington, DC: Association of Official Analytical Chemists.

Balaban, MO, Chombeau, M, Gümüs, B, Cirban, D. 201 2. Quality Evaluation of Alaska Pollock (Theragra chalcogramma) Roe by Image Analysis. Part I: Weight Prediction. Journal of Aquatic Food Product Technology, 21(1): 59-71.

Reports and factsheets on responsible sourcing. 2011. Responsible Sourcing Guide: Alaska pollock roe, 4: 1-9

Broadus JM, Raphael VV. 1994. Living resource problems. In: Broadus JM, Raphael VV, editors. The oceans and environmental security. Covelo, Calif.: Island Press: 50-85. 